\title{
The Impact of Human Rights Violation Concerning the Status of Women and Children in Bangladesh: A Critical Review
}

\author{
Md. Nahidul Islam* \\ Department of Law, Gono Bishwabidyalay, Savar, Dhaka-1344, Bangladesh. \\ *Correspondence: jsnahid07law@gmail.com (Dr. Md. Nahidul Islam, Assistant Professor, Gono Bishwabidyalay, Dhaka).
}

\begin{abstract}
This paper is basically concerned with the status of Women and Children relating to the violation of human rights and its impact. This paper mostly dwells on certain examples of violation of human rights relating to torture, sexual harassment, trafficking and sexual exploitation, rape, and murder or even the violation of domestic workers' rights emphasizing on the human rights situation in a democratic and a developing country like Bangladesh. In this study, in addition to this, an attempt has been made to unveil the relationship between Human Rights and Police Administration. Most importantly, there is a further attempt to uphold the facts of human rights' violations especially concerning the status of women and children mentioning and studying certain sensational cases too. Finally, in this paper, the researcher has endeavored to bring out the actual situation and impact of such violations analyzing and reviewing critically the status of women and children as well as the indigenous community i.e., the rights of indigenous women and children in Bangladesh too and certain facts in different perspectives in connection with the activities of the law enforcers i.e., the police where these agencies are always on action having the responsibilities to protect and ensure the human rights of the citizens in a democratic and developing country like Bangladesh.
\end{abstract}

Keywords: Impact, Human rights, Violation, Women and children, Police, Bangladesh, and Critical review.

\section{INTRODUCTION:}

At the outset of this study, it can be said that a democratic and developing country like Bangladesh faced certain human rights violations nationally and internationally. Eventually, being deprived from their international rights whatsoever the application of the international law is whether perfectly implemented or not, it is question. The same thing is there for the proper application and implementation of rule of law in a country like Bangladesh. And this misconception and awful practice, practiced by the law enforcers' rampantly don't make sense of the proper application of rule of law and compels to make violations in every spheres of human beings and occurred unnecessary and unexpected incidents or conflicts like violation of human rights relating to torture, sexual harassment, trafficking and sexual exploitation, rape and murder or even the violation of domestic workers' i.e., over all human rights violation concerning the Status of Women and Children in Bangladesh (Islam, 2019).

In this paper, the researcher tried to endeavor to find out the actual scenario of the impact of human rights violation concerning the status of women and children in Bangladesh mentioning certain loopholes and findings along with certain recommendations after a series of certain documentary analysis through a 
critical review on the basis of ensuring justice for the women and children in a democratic and developing country like Bangladesh. What is considered to be an offense, and which means violation of the rights? When a common man does anything which is illegal in law and punishable by the court of law in a state is a crime and he who commits it, is called a criminal in the eye of law and he is guilty in this regard. But it is a matter of fact that if the protector is a spoiler, it means violating the rights.

So, in this connection, it would not be out of place to mention that if the police, as the keeper, does not establish the rights of the common people, but rather assaults them and by misusing their power, then it is called the violation of rights i.e., the human rights violations committed by the police. In a democratic and developing country like Bangladesh, human rights situation is not a small issue. It is observer by the researcher that human rights in this country are being violated in different ways. These so called violations are being done not only day after day by the police but also by various government and non-government organizations of the country are responsible for it. But since police breaches are the subject to this study, then the researcher tried his best attempt to hold up the overall situation of human rights relating to violation of human rights in Bangladesh especially in extrajudicial activities through his write-up. Therefore, while studying by the researcher in this connection, it would not be out of place to start mentioning through a common conception of the common people mentioned below to clear out attitude towards the law enforcement agency i.e., the police in a democratic country like Bangladesh.

If it is said about the issue of rights, then in different perspectives, it can be noticed that people do not like to go to the police station to file a complaint. It does not feel very good to go there thinking that there will be more problems may have to be faced in the police station. In essence, by the expenditure of money, they will have to be directed to the police for their due rights. So here's the money to get right and just like getting the right to exchange money. Though the facts are incredible, it is true and difficult to believe that it is a real picture that police do not want to receive UniversePG I www.universepg.com complaints in many cases not only in a democratic country like Bangladesh but also in other subcontinental countries. Since it involves questions of money and ethics thereto, therefore it is really a matter of great regret that such ideas have been developed among the most of the people in Bangladesh. Consequently, the creation of public interest in this trust is getting clear form of violation of human rights by the police now-a-days.

In fact, this kind of negative attitude towards the police was not built in a day by the common people in this country, but it is the result of some of the corrupt members of the police community though in every sector however in every such government and nongovernment organization. There are certain numbers of corrupt persons still involved. In this connection, it must be mentioned that those corrupt personnel were also under the process of law at present. Furthermore, the number of honest and qualified police is not low at present too and they are always ready to serve people the best afford ever. Even then, it is a burning question of the day why the negative thinking is still prevailing in the heart of the common citizen in a state like Bangladesh. So therefore, the concept of violation of human rights by the police is now a matter of under the real study. That is why it became an ultimate responsibility of the law enforcers to make people turned in the right direction wherefrom such a strong idea i.e., the traditional concept against the police. In this connection, it must be mentioned that on 6 March and 7 March 2017 in Geneva, the United Nations Human Rights Committee reviewed the progress of Bangladesh in implementing the Civil and Political Rights regarding the sections of International Charter. In this review the United Nations Human Rights Committee has expressed their concerns i.e., anxieties and recommendations on matters related to civil and political rights are:

Extra-judicial Killings, Forced disappearance, Torture and death in Custody, Freedom of Expression, Death Sentence, Prison Situation, Strengthen the National Human Rights Commission, Prevention of Terrorism, Gender, Religion, Caste and Ethnic Discrimination, Child Marriage and its harmful social practice, Rights of Refugees and Political Asylum Seekers. In this 
context, the researcher has an attempt after reviewing the situation of Civil and Political Rights of Bangladesh especially in 2016 and 2017, a worrying figure arises. Therefore, some of the recent and nearest past incidents that occurred in different years including in 2016 and 2017 have been discussed thoroughly here below with relevant references one after another which refers to human rights violations occurred by the law enforcement agency i.e., by the police in a democratic country like Bangladesh.

\section{STATUS OF WOMEN IN HUMAN RIGHTS SITUATION IN BANGLADESH}

In the context of the condition of women in the human rights situation of Bangladesh, two important issues are the prime discussions of it:
1. Women's participation in economic-socialpolitical life

2. Situation of Women's torture

Most importantly, it is to be noted that the researcher has been studying the situation of human rights in Bangladesh perspective and as violation is an essential part of this chapter of the study, so therefore the researcher has an attempt to discuss the situation of women's torture in the context of 2016 over here. However, from the point of this view, in this regard, the status of women in human rights situation in Bangladesh has been briefly discussed here below. In this regard, The Image of Women's Torture in the context of the recent year 2016 has been discussed in the Table 1.

Table 1: The Image of Women's Torture (January-December, 2016) regarding Rape and Rape Attempt

\begin{tabular}{|c|c|c|c|c|c|c|c|c|}
\hline \multirow[t]{2}{*}{ Type } & \multicolumn{6}{|c|}{ Age } & \multirow{2}{*}{$\begin{array}{c}\text { Age not } \\
\text { mentioned }\end{array}$} & \multirow[t]{2}{*}{ Total } \\
\hline & $0-6$ & $7-12$ & 13-18 & $19-24$ & 25-30 & $30+$ & & \\
\hline Rape Attempt & 10 & 19 & 16 & - & 1 & - & 19 & 65 \\
\hline Single Raped & 50 & 144 & 147 & 20 & 5 & 8 & 70 & 444 \\
\hline Gang Raped & 1 & 14 & 82 & 12 & 6 & 5 & 77 & 197 \\
\hline Type of Rape not Mentioned & 1 & 1 & 6 & 4 & 3 & - & 3 & 18 \\
\hline Total & 62 & 178 & 251 & 36 & 15 & 13 & 169 & 724 \\
\hline Rape post murder & 1 & 11 & 8 & 6 & 4 & - & 7 & 37 \\
\hline Suicide due to rape & - & - & 6 & 1 & - & - & 1 & 8 \\
\hline
\end{tabular}

After analyzing the Table 1 mentioned above, it has been observed that comparatively the incident of single raped placed first and the number of victims were 444 . It is to be reported that 147 among the number of 444 , their age were mostly (13-18) only and the incident of suicide due to rape took the lowest place in context of women's torture and it was only 8 where only 6 victims among them committed suicide due to rape and furthermore, it must be pointed that in suicide case their age were mostly (13-18).

However, the concept of Image of Women's Torture (January-December, 2016) regarding rape and rape attempt in the name of violation of human rights in a democratic and developing country like Bangladesh are to be more justified after discussing relevant Cases' Study here below:

\section{Case Study-2.1: Rape and Murder of Sohagi Jahan Tonu}

Sohagi Jahan Tonu was a second year student in the department of History in Comilla Victoria College and a member of Theatre in that college too. She was connected to various cultural activities there. She used to live in the Comilla Cantonment's power House Residential Area on her father's job source. On March 20, 2016; for the purpose of teaching private, Tonu went to Alipur Staff Quarter in the area of Cantonment. In the connection of this incident, as she did not return home for late nights, then her father Md. Yaar Hossain found her daughter unconscious and injured in the forest under the culvert, about 300 yards away from cantonment girls' high school beside her house while on going to find Tonu. Then immediately, tonu had been brought to the combined military hospital but to the duty doctor declared her dead then. 
On March 21, 2016; she was buried in her village home at Mirzapur, Muradnagar Thana. Countrywide, this incident has been extensively discussed and criticized among the different social media, mass media and even in face book. It was not end here; this incident made country-wide a storm of protests among the Human Rights, Women and student organizations including in different organizations too. Regarding the rape and murder of Tonu, her father filed a case (No. 65 Date21-03-2016) against unknown miscreants in Comilla Sadar Police Station.

In addition to this incident, it must be mentioned that after recovering the body, police, based on the findings at the crime scene, had said that the girl was first raped and then murdered. On March 30, 2016; the body of Tonu was raised for the further autopsy according to the order of the Court. In this connection, it is to be reported that after two post-mortem examination, the forensic department report of Comilla Medical College did not mention any apparent cause of Tonu's death. Although the years have passed after this incident, there has not been detected the criminals yet.
Case Study-2.2: A Six year-old Female Child Raped in Dinajpur

To mention briefly, this rape incident has been known after publishing it in the Bangla Tribue on November 16,2016 that a six year-old female child in Birganj Upazila, Dinajpur. It was happened when the victim's mother kept her child in the same area of the house of the accused named Motiur Rahman for the sake of visiting her father's house and on that night Motiur Rahman raped the child and fled away. Later on, a case had been filed in Birganj Police Station on November 16, 2016. In addition to this, it must be reported and observed that before filling the case, the child had been admitted firstly to Upazila Health Complex for the deterioration of her physical condition on November 14, 2106. But as there victim's condition worsened even further and then again she had to admit finally in Dinajpur Medical College Hospital on November 16, 2016. The police arrested the accused in connection with the investigation of the incident. Now, Sexual Harassment and Violence committed by the Stalkers' of the recent year 2016 has been discussed in the Table 2.

Table 2: Sexual Harassment and Violence (Nuisance of the Stalkers')

\begin{tabular}{|l|c|c|c|}
\hline Type & Number of Female & Number of Male & Total \\
\hline Suicide & 6 & - & 6 \\
\hline Attempt to Suicide & - & - & 0 \\
\hline Murder due to protest & 7 & 7 & 14 \\
\hline Humiliated by the Stalker for protesting harassment & 138 & 20 & 158 \\
\hline Centered conflict of the stalkers' caused certain injury & - & 61 & 61 \\
\hline Stop going to School & 5 & - & 5 \\
\hline Total & $\mathbf{1 5 6}$ & $\mathbf{8 8}$ & $\mathbf{2 4 4}$ \\
\hline
\end{tabular}

After analyzing the Table 2 mentioned above, it prescribes that among the 244 victims, it has been observed that mostly 138 female has been Humiliated by the Stalker for protesting harassment; and mostly 61 male has been Centered conflict of the stalkers' caused certain injury; 6 female has committed Suicide; 7 male and female are Murdered due to protest sexual harassment and violence on committing nuisance of the stalkers' and 5 female has stopped going to school also. Now the relevant cases regarding sexual harassment and violence on committing nuisance of the stalkers' have been mentioned here below:

UniversePG I www.universepg.com
Case Study-2.3: Sexual Harassment and Violence (Nuisance of Stalker) in the Capital

Willes Little Flower School student Suraiya Akter Risha (14) has died at Dhaka Medical College Hospital $(\mathrm{DMCH})$ three days after being knifed on August 24, 2016 by a miscreant named Obayedul Khan due to spurn love.

\section{Case Study-2.4: Sexual Harassment and Violence (Nuisance of Stalker) at MC College Sylhet}

On October 3, 2016; Khadija Akhter Nargis (23), a second year honours student of the Sylhet Government 
Women's College, was attacked on her way home from the college by Badrul Alam (30), a leader of the Bangladesh Chhatra League (BCL) and assistant secretary of the BCL unit at Shahjalal University of Science and Technology (SUST), student wing of the Awami League, stabbed her head repeatedly with a machete and sharp weapon in broad daylight due to spurn love. In addition to this, it is pertinent to be mentioned that in a press statement, the central Chhatra League refused to take any responsibility for the attack on Khadija. It said Badrul is no longer a leader or activist of the BCL. There is no relation between the BCL and Badrul. Talking to the media, home minister Asaduzzaman Khan Kamal said on October 4, 2016; that a criminal does not belong to a party or organization. Action will be taken against the attacker irrespective of his party affiliation.

However, finally the victim Khadija got riskfree from danger after the ending treatment for 57 days at Square Hospital in the Capital. Now the researcher has an attempt to up hold the actual scenario of Arbitration and Fatwa in the year of 2016 in the Table 3 mentioned below:

Table 3: The Scenario of Arbitration and Fatwa -2016

\begin{tabular}{|l|c|c|c|c|c|c|}
\hline \multirow{2}{*}{ Cause List } & \multicolumn{5}{|c|}{ Methods } \\
\cline { 2 - 7 } & $\begin{array}{c}\text { Hilla } \\
\text { Marriage }\end{array}$ & $\begin{array}{c}\text { Punishment } \\
\text { by Dorra } \\
\text { (whipped by } \\
\text { Striped) }\end{array}$ & $\begin{array}{c}\text { Disfigured } \\
\text { from } \\
\text { village/society } \\
\text { or kept lonely }\end{array}$ & $\begin{array}{c}\text { Physical } \\
\text { Torture }\end{array}$ & Total & $\begin{array}{c}\text { Number } \\
\text { of Cases }\end{array}$ \\
\hline Making Love & - & - & - & 1 & 1 & 1 \\
\hline Oral divorce & 1 & - & 3 & - & 4 & 0 \\
\hline Rape/Rape Attempt & - & 1 & - & - & 1 & 0 \\
\hline False accusations of character & - & - & 1 & 2 & 3 & 2 \\
\hline Offence for marrying & - & - & - & 1 & 1 & 0 \\
\hline $\begin{array}{l}\text { In connection with physical } \\
\text { relations }\end{array}$ & - & 1 & - & - & 1 & 0 \\
\hline Cause not mentioned & - & - & - & 1 & 1 & 0 \\
\hline Total & $\mathbf{1}$ & $\mathbf{2}$ & $\mathbf{4}$ & $\mathbf{5}$ & $\mathbf{1 2}$ & $\mathbf{3}$ \\
\hline
\end{tabular}

After analyzing the Table $\mathbf{3}$ mentioned above, it shows that the case mostly have been filed 2 cases among the 3 due to false accusations of character and comparatively, more punishments are given especially for Oral divorce and it is 3 among the 4 . In this connection, it is to be mentioned that the number of punishment for disfigured from village/society or kept lonely is 4 among 12 have been given in such Arbitration and Fatwa-2016. Therefore, it has been observed that 12 numbers of Arbitration and Fatwa have been held despite being legally banned.

Additionally it is to be noted that such information got from after publishing the news through different mass media and several responsible persons were involved in such arbitration in this regard.
Case Study-2.5: Arbitration and Fatwa Image at Mahmudpur Village, Badalgashi, Naogaon.

On October 29, 2016; daughter nemed Champa Parvin and her mother named Sonavan at Mahmudpur Union, Badalgachhi, Naogaon were brutally tortured by hanging and tied on the tree in the name of Arbitration (Salish) by the Local Union Parishad Chairman, Abdur Rahman, and his associates.

\section{Case Study-2.6: Arbitration and Fatwa Image at Khasnagar Village, Serajdikhan Upazila.}

On October 23, 2016; published in the Daily Samakal; at Khash Nangar, Baluchar Union, Sirajdikhan. In this incident, a woman has been raped by the accused named Babul Mia son of Abul Kashem, khasnagar Southpara village. In the case UP Chairman sat on arbitration (Salish) along with some locally influenced 
persons in this regard. But it is to be noted that despite getting the truth of the incident, the rapist Babul Mia has been held $30000 \mathrm{Tk}$. (Thirty Thousand Tk.)for fine and along with 50 stripes as a punishment for committing rape in the name of justice in a democratic and developing country like Bangladesh. Now the scenario of family torture regarding violation of human rights women in Bangladesh has been shown briefly through The Table 4 mentioned here below:

Table 4: Scenario of Family Torture

\begin{tabular}{|l|c|c|c|c|c|c|}
\hline \multirow{2}{*}{ Torture Type } & \multicolumn{7}{c|}{ Age } & \multirow{2}{*}{ Total } \\
\cline { 2 - 7 } & $\mathbf{7 - 1 8}$ & $\mathbf{1 9 - 2 4}$ & $\mathbf{2 5 - 3 0}$ & $\mathbf{3 0 +}$ & Age not mentioned & \\
\hline Tortured by Husband & 2 & 6 & 15 & 3 & 24 & 50 \\
\hline Tortured by Husband's Family & - & 3 & 2 & - & 9 & 14 \\
\hline Killed by Husband & 15 & 56 & 56 & 28 & 36 & 191 \\
\hline Killed by Husband's Family & 2 & 21 & 17 & 7 & 6 & 53 \\
\hline Killed by her family & 2 & 2 & - & 18 & 4 & 26 \\
\hline Tortured by her family & - & - & - & 9 & 6 & 15 \\
\hline Suicide & 2 & 11 & 16 & 10 & 6 & 45 \\
\hline Total & $\mathbf{2 3}$ & $\mathbf{9 9}$ & $\mathbf{1 0 6}$ & $\mathbf{7 5}$ & $\mathbf{9 1}$ & $\mathbf{3 9 4}$ \\
\hline
\end{tabular}

After analyzing the Table 4 mentioned above, it shows that mostly 15 females have been tortured by husband among the 50 whose ages are (25-30); mostly 56 females have been killed by her husband among 191 whose ages are (19-24) and (25-30) accordingly; mostly 21 females have been killed by husband's family among the 53 whose ages are (19-24); mostly 18 females have been killed by her family among 26 whose ages are above 30; and mostly 16 females have been committed suicide among 45 whose ages are (2530 ) in this regard. Furthermore, from the point of views mentioned above regarding the status of Women in human rights situation in Bangladesh, it may be mentioned certain cases relating to this issue for the justification of the recent past of the violations of women in a democratic and developing country like Bangladesh.

Despite many deterrent measures taken by the government and the administration, sexual harassment and stalking of women and girls has acted as a serious threat to the security of young school and college going women. In some cases the stalkers attacked those who protested sexual harassment. On November 26, 2011, in Barisal district, the stalkers stabbed Md. Jinat Ali, a school teacher and freedom fighter to death, when he protested harassment of his daughter and informed the police. In 2011, 33 women and girls committed suicide because they were being stalked and 23 were killed by the stalkers for protesting such acts. Despite Appellate Division's judgment declaring extra judicial punishment in the name of fatwa to be a criminal offense, the number of incidents of violence against women in the name of fatwa or Salish (traditional arbitration) had increased in 2011 compared to the previous year. This year, 59 women had been subjected to torture by Salish or issuing of fatwa. In several incidents, elected public representatives, local union council chairmen and members, local influential, political leaders played a leading role in inflicting violence during Salish (mediation). Recently, the electronic channel showed a video of barbaric torture on two housewives, Happy and Shahida, at Badarganj, in Rangpur district, following a Salish decision. In another incident, in Shariatpur district, a teenage girl Hena was raped by her cousin Mahabub. But the village Salish ordered Hena to be flogged. When she became unconscious, she was admitted to the local health centre, but the fatwa-givers forcibly sent her home from the hospital, where she died without treatment. Torture or humiliation in the name of Fatwa is not only confined to women, rather such practices are used against people of different religions and cultures. On April 4, 2011, in Rajbari district, the local Mufti (Islamic cleric) Riaz declared a fatwa at a Salish against Bauls (a community of bards practicing their 
own culture with distinct religious belief), who joined a Baul song festival. Their head, mustache and beards were forcibly shaved, and they were taken to a nearby Mosque for conversion to Islam by pronouncing tauba, (repentance) which is very alarming.

Recently, a new dimension has been added to violence against women through misuse of information technology by recording and releasing of obscene video clips. Such offenses are committed by close relations of the victims such as husbands, boyfriends or lovers as well as by rapists. Parimal, a teacher of the Viqarunnissa Noon School, not only raped his student; he also allegedly recorded the occurrence. Such recordings have even led to suicide by the victim. This year, 42 women were subjected to harassment/torture through misuse of information technology and two of them committed suicide. In this year, 502 women were subjected to violence for dowry demands, 62 were victims of acid violence and 782 were raped. Reportedly, 117 domestic workers were tortured this year. The emigrant husband of Hawa Akter Jui, a student of class twelve at the Narsingdi Government College, cut off four fingers from her right hand, because he disapproved of Jui's desire to continue her studies. Therefore, after reviewing the incidents of past and near past violations regarding this issue, it is to be noted that still now violations have been committed in many ways against the rights of the women in a developing country like Bangladesh.

\section{VIOLATION OF CHILDREN RIGHTS IN BANGLADESH}

At the outset of the discussion, it is pertinent to mention that in a democratic and developing country like Bangladesh the issue of violation of children rights have been occupied as a regular phenomenon. In this connection, it can be said that through different social media and mass media or even in face book there have a lot of examples of such cases of torturing and inhumane treatment towards the children. Not only the children in this democratic and developing country are being tortured severely or harassed but also died of extreme violation of human rights. In this regard, it would not be out of place to mention that a total of 968 children were tortured to death in last three and half-a-years says child rights defender Bangladesh Shishu Adhikar Forum in a recent study. In addition to this, the children's rights have been violated through tortured to death, beating, trafficking and sexual exploitation, child labor, improper application of law and mismanagement by the social organizations i.e., child welfare institutions, Torture in Educational institutions, wrong application of law towards the children and also by the extreme mistake made by the law enforcers and even by the violence of family. Now the common reasons and methods of child torture i.e., harassment as well as certain scenario of children tortured to deaths with relevant references in the society of a country like Bangladesh have been briefly stated through certain Case Study and showing tables below.

\section{Torture of Children}

At the outset, it would be mentioned that there are so many common reasons and methods of torturing in the name of awarding punishments' towards the children in our society. Such as- Making mischief, being minorities, lost money, attending madrasha without cutting hair, attending school without wearing uniform, cannot read, guardian's complain, come without preparation in school, making fight, making theft of others things, making theft of others phone, do not come to private, seeking out the holiday, do not able to answer question, disobeying teacher, absent mind in study, study gap, talking while teacher taking class etc. Additionally, it may be mentioned that there are some punishments awarded to children by the educational institutions like school and madrasha which is still been observed in a democratic and developing country like Bangladesh.

Actually children in this country are being tortured as punishments in the name of governance such foot washed water is fed, hair is cut by force as punishment by whipped mental torture, beating/various types of physical injuries etcetera. In fact, violence in the name of discipline for the children gradually increasing day by day in our civil society. Although these treatments mentioned above have been totally prohibited by the certain domestic laws and several international instruments adopted by the government. 


\section{Case Study 3.1 Months Old Baby in theft and Vandalism Case}

An 11 months old baby named Rubel son of Abul Kashem has been charged for theft and vandalism case by a police officer in the capital Dhaka. When case was filed, Rubel's was only 28 day's baby. Actually this type of case is not new in Bangladesh. A man named Habibur filed that case on June 26, 2016 at Mirpur Police Station. The IO (Investigating Officer) SI Maruful Islam, February 27, 2017 submitted charge sheet against 23 persons including Arifur Rahman. It was known from there that when it a was shown the accused Rubel (30), then he was only 11 Months. Dhaka Metropolitan Police has temporary suspended SI Maruful Islam. According to him, SI Maruful Islam has been suspended and departmental investigation is running. It has been proved that the primary investigation that he gave charge sheet without investigating the case. And he did not justify the age and address of the accused accordingly. Neglect in the investigation is clear.

\section{Case Study 3.2 Years Old Sajib in Rape Case at Jhenaidah}

On April 25, 2015; 7 years old children named Sajib has been charged in a rape case. June 30, 2017, IO submitted charge sheet to the Court and age was shown 10 in that charge sheet. He came for bail on his father's ladders. Sajib was a student of Class Two. During the incident, it was known that in that rape case, Rony called the victim for the sake of rapist. So, Rony was charged as an accused for being an associate in that rape case. Thus, from the point of view through case study discussed above regarding relevant cases relating to the children, it must be noted that in that three cases, those children has been victimized of extreme harassment which was illegal in the eye of law and which violated certain domestic laws and several international instruments.

Therefore, it is pertinent to mention that there has been extreme violation of human rights has been committed by the law enforcers i.e., by the police which is never be expected and accepted in a democratic and developing country like Bangladesh.

\section{Case Study 3.3 Years Old Rony at Sherpur}

Children in Bangladesh has been charged illegally is not new one. May 2, 2017; 5 Year Old Rony came to Sherpur Chief Metropolitan Magistrate Court for bail on his uncle's ladders. He has been accused for vandalism and Riot. In this regard, a relevant incident in reference of relating to children tortured by the police along with a woman in 2011 may be mentioned here below:

\section{Case Study 3.4: Five people including three children, were allegedly tortured at Lalbagh Police Station custody in Dhaka}

On September 04, 2011, police of Lalbagh Police Station, Dhaka arrested Akhi Aktar (7) and Barek Haolader (8), daughter and son of Babul Haolader; and Moksed Shikder (32), his wife Shajeda Begum (30). On September 07, 2011 Moksed and Shajeda's son Mirajul Shikder (6) was arrested by them on allegations of theft. Most importantly, it is to be noted that Police confined and allegedly tortured the three children for 6 days from 4-10 September, 2011 and treated Moksed and Shajeda the same way for two days.

\section{Odhikar's Statement}

The plaintiff Mohammad Mahbubur Rahman's relative Mohammad Momin Ali and police refused to give any information of plaintiff's son in law and another domestic help. Law in Bangladesh bars the employment of underage children as domestic help. Police did not take any action against the plaintiff for employing a child of 7 years as a domestic help. The Government cannot ensure the right to food, clothes and security of minors; moreover, the police tortured the three children and a woman. Now the scenario of Children Tortured and Children Killed in 2016 has been mention in the Table 5.

After analyzing the Table 5, it shows that 1038 children have been the victims of torture and 465 children have been killed in the year of 2016 according to the ASK Data Conservation Unit's Statistics -2016. Now the Statistics of Sexual Torture by abusing the use of Internet: January 2011December 2016 have been mentioned in the Table 6. 
Table 5: The Scenario of Children Tortured and Children Killed-2016

\begin{tabular}{|c|c|c|c|c|c|c|}
\hline \multirow{2}{*}{ Subject } & \multicolumn{4}{|c|}{ Age } & \multirow{2}{*}{ Total } & \multirow{2}{*}{ Number of Cases } \\
\cline { 2 - 5 } & $\mathbf{0 - 6}$ & $\mathbf{7 - 1 2}$ & $\mathbf{1 3 - 1 8}$ & Age not mentioned & & \\
\hline Children Tortured & 80 & 327 & 370 & 257 & 1034 & 260 \\
\hline Child Killed & 124 & 133 & 186 & 22 & 465 & 176 \\
\hline
\end{tabular}

Sources: Data collected from the Prothom Alo, the Daily Sangbad, the Daily Ittefaq, the Daily Nayadiganta, the Daily Star, the Daily New Age, Dhaka Tribune and Ain o Salish Kendra (ASK).

Table 6: Statistics of Sexual Torture by abusing the use of Internet: January 2011-December 2016

\begin{tabular}{|c|c|c|c|c|c|}
\hline \multirow[t]{2}{*}{ Year } & \multicolumn{4}{|c|}{ Age } & \multirow[t]{2}{*}{ Total } \\
\hline & 11-14 & $15-18$ & Above 19 & Age not mentioned & \\
\hline 2011 & 5 & 8 & 3 & 19 & 35 \\
\hline 2012 & 5 & 9 & - & 37 & 51 \\
\hline 2013 & 1 & - & - & 6 & 7 \\
\hline 2014 & 2 & 5 & 1 & 90 & 98 \\
\hline 2015 & 4 & - & 3 & 5 & 12 \\
\hline 2016 & 1 & 2 & - & 21 & 24 \\
\hline \multicolumn{5}{|l|}{ Total } & 227 \\
\hline
\end{tabular}

After analyzing the Table 6 mentioned above, it shows that mostly teenagers and young people are increasingly being victimized and tortured through online in Bangladesh. Everyday Police receive 10 to 12 harassment complaints of online on average. In addition to this, it must be reported that with the rise of smart phone use in Bangladesh, the online harassment of women has also grown manifold, according to authorities. The primary target of the online abusers is teenage girls, say police. $90 \%$ percent of the victims are pre-teen and teenage girls. According to Ain O Sailsh Kendra (ASK) Data Conservation Unit's Statistics -2016, total 24 persons have been victimized of sexual torture and harassment by online. Of which twenty-one are children (Their age is not mentioned, but it is understood through newspaper that their age is under eighteen years of old).

\section{CHILD TRAFFICKING AND SEXUAL EXPLOITATION}

The issue of child sexual abuse is very much like the prohibited subject in a democratic and developing country like Bangladesh. Sexual exploitation of brothel hotels and street-borne children begins from the age of only ten years. Many children in the brothel are forced to work as slaves. Approximately forty thousand street children are at risk due to such exploitation. Despite the significant progress of human trafficking, the proper justice of the rescued people from the trafficking of Bangladesh receipt and trafficking were not fully competent in the trial and execution of traffickers.

For this reason, the State Department's Human Trafficking Report has been ranked second Bangladesh in the ranking for the second consecutive year. Concerned agencies could not build large institutional structures to create awareness amongst the victims of exploitation, it also failed to take enough initiative to get legal remedies. Apart from this, the government had a major weakness in not being able to monitor the initiatives taken. Besides, there is a lack of proper initiative for the victims of trafficking, who are working in brothels and domestic workers and those who have returned through rescue. Therefore, the government should be more and more active to take necessary and positive steps for ensuring human rights in a democratic and developing country as because of children are a big part of the population in Bangladesh. 


\section{VIOLATION OF DOMESTIC WORKERS' RIGHTS}

Human rights violation is a violation of the rights of Domestic Workers' in a democratic and developing country like Bangladesh. In reality, there are enough examples of this violation not only it is in the newspapers. Now Violation of Domestic Workers' Rights have been mentioned through torture of domestic workers' according to Ain o Sailsh Kendra (ASK) Data Conservation Unit's Statistics -2016 in the Table 7.

Table 7: Torture of Domestic Workers'-2016

\begin{tabular}{|l|c|c|c|c|c|c|c|c|c|}
\hline \multirow{2}{*}{ Type of Torture } & \multicolumn{5}{|c|}{ Age } & $\begin{array}{c}\text { Age not } \\
\text { mentioned }\end{array}$ & Total & $\begin{array}{c}\text { Number } \\
\text { of Cases }\end{array}$ \\
\cline { 2 - 11 } & $\mathbf{0 - 6}$ & $\mathbf{7 - 1 2}$ & $\mathbf{1 3 - 1 8}$ & $\mathbf{1 9 - 2 4}$ & $\mathbf{2 5 - 3 0}$ & $\mathbf{3 0 +}$ & -1 & 12 \\
\hline Physical Torture & 1 & 8 & 2 & - & 1 & 2 & 7 & 21 & 2 \\
\hline Rape & - & - & 1 & - & - & - & 1 & 2 & 11 \\
\hline $\begin{array}{l}\text { Type of Torture not } \\
\text { mentioned (Death) }\end{array}$ & - & 1 & 17 & - & 4 & - & 5 & 27 & 1 \\
\hline Rape post murder & - & - & 1 & - & - & - & - & 1 & 1 \\
\hline Death after physical torture & - & 4 & 1 & - & - & 1 & 1 & 7 & 6 \\
\hline Suicide & - & - & 4 & 1 & - & - & - & 5 & - \\
\hline Attempt to Suicide & - & - & 1 & - & - & - & - & 1 & - \\
\hline Total & $\mathbf{1}$ & $\mathbf{1 3}$ & $\mathbf{2 7}$ & $\mathbf{1}$ & $\mathbf{5}$ & $\mathbf{3}$ & $\mathbf{1 4}$ & $\mathbf{6 4}$ & $\mathbf{3 2}$ \\
\hline
\end{tabular}

Sources: Data collected from the Prothom Alo, the Daily Sangbad, the Daily Ittefaq, the Daily Nayadiganta, the Daily Star, the Daily New Age, Dhaka Tribune and Ain o Salish Kendra (ASK).

After analyzing the Table 7, it shows that through it shows that mostly 17 females have died but type of torture not mentioned among 27 whose ages are (1318 ); mostly 8 females have been victimized to Physical Torture among 21 whose ages are (7-12); mostly 4 females have been died after physical torture among 7 whose ages are (7-12); mostly 4 females committed suicide among 5 whose ages are (13-18). In this regard, maximum cases are filed for physical torture and then the second most cases are filed for death but type of torture not mentioned here according to the table shown above.

\section{VIOLATION OF HUMAN RIGHTS OF THE INDIGENOUS COMMUNITY SPECIALLY THE RIGHTS OF INDIGENOUS WOMEN AND CHILDREN IN BANGLADESH}

At the outset, reviewing the issue regarding the violation of human rights of the indigenous community specially the rights of indigenous women and children in Bangladesh from different social media and mass media along with the observation and related references, it would be pertinent to mention that hundreds of human rights violations have occurred on indigenous women and children in 2016. Among these 28 violations have been occurred in Chittagong Hill Tracts and 25 on flat land. Minimum 58 numbers of women and children have been the victim of torture, rape and murder in that incident. In this incident, 6 indigenous women and children have been killed after raped. In this incident, those children are been more victimized whose age is fewer than 18 .

Analyzing the incidents occurred on the Hill Tracts and on flat land, it has been found that in this incident settler Bengali at Chittagong Hill Tracts and member of law enforcing agency in few cases are related. Furthermore, it would not be out of place to mention that most of the incidents have been occurred by the indigenous on flat. It is a matter of great regret that recently the indigenous men became involved in such crimes. As a consequence, indigenous women are more likely to suffer from discrimination and abuse more from all around. In addition to this, it is pertinently has been reported during the year of 2011 that there had been progress in implementing of 
Chittagong Hill Tracts Accord since it was signed on December 2, 2011.

In this connection, the settlement of land disputes in the Chittagong Hill Tracts had not proceeded because the Adibashis ownership of land is communal, but the Bengali settlers had registered their allocated land as individuals, and allegedly taken over some land belonging to the Adibashis. In Council of advisors to the concerned ministry remains ineffective. District councils consisting of members nominated by the government instead of elected ones is unable to play an effective role in development relating to public interest. As a result violent clashes between the two communities have exacerbated political conflicts, ethnic and communal clashes and provoked violence against women.

Finally, it is to be noted and observed that after analyzing the fact mentioned above, there should have the proper and strong interference of the government for taking actions against such crimes in this regard for the sake of protecting the rights of such indigenous community as well as especially the rights of indigenous women and children in Bangladesh. In this connection, the law enforcing agencies to be more active in their duties to protect those indigenous victims' rights i.e., the indigenous women and children and criminals should be brought to justice and one day it will be happened when the law enforcers would be more proactive in their duties and responsibilities for the sake of ensuring human rights for the all citizens, for all the communities whether it would be minorities or majorities in a democratic and developing country like Bangladesh.

\section{FINDINGS AND RECOMMENDATIONS:}

During analysis of the study, the researcher has found certain loopholes and findings along with certain recommendations regarding the impact of human rights violation especially concerning the status of women and children in a democratic and developing countries like Bangladesh are mentioned here below:

1. In addition to this, it is observed that the activities of the law enforcers have been moderated through different methods of committing violations where the accountability has become covered by the illegal practice of law.

2. Therefore, certain domestic laws and international instruments have been grossly violated in action of dramatic role of the law enforcers i.e., the police. Even more, the guidelines directed by the supreme institution i.e., have not been properly followed rather been violated rampantly.

3. Most importantly, it is to be mentioned that political influences worked largely in every sphere of conducting services towards the citizens.

4. Furthermore, countrywide violation of human rights loomed among the people become more ferocious to commit crimes again and again thinking that justice never be done by the law enforcers where this agencies have already become more corrupted.

5. After critical analysis regarding the violation of human rights, it has been observed that recruitment of the law enforcement agencies i.e., the police,' should be strictly maintained to hold the fair appointment. Therefore, finally it can be said that the government should strictly maintain the quality police appointing in the law and order perspective where there would be absolute transparent of accountability to be ensured regarding the violation of human rights in Bangladesh.

6. Indeed, there should have the necessary action taken by the government in all circumstances for establishing rule of law. Because if the rule of law i.e., the proper implementation and application of law could be ensured in a democratic country like Bangladesh, then it would not be difficult to ensure human rights in a democratic and developing country like Bangladesh.

Finally, after a critical review of of this study on the violation of human rights in respect of the status of women and children, concerned with certain years' reports reported in different human rights organizations and mass media in a country like Bangladesh, it would not be out of place to mention that reported violations of human rights played and directed nothing expected positive role of this law enforcing agencies i.e., the 
police until or unless the actual practice and proper application of rule of law are to be established and ensured by the government accordingly in a democratic and developing country like Bangladesh.

\section{CONCLUSION:}

This paper has attempted to prove a concrete impact of human rights violation especially concerning the status of women and children in Bangladesh. After a critical review of the study, it has been noticed and observed by the researcher that lots of extreme violations such as torture, sexual harassment, trafficking and sexual exploitation, rape and murder or even the violation of domestic workers' have been occurred and still alarmingly increasing day by day. Eventually, it has been found that analyzing the incidents occurred on the Hill Tracts and on flat land, it has been found that in this incident settler Bengali at Chittagong Hill Tracts and member of law enforcing agency in few cases are related. So therefore, it is crystal clear to observe that the activities of the law enforcers have been moderated through different methods of committing violations where the accountability have become covered by the illegal practice of law. Therefore, certain domestic laws and international instruments have been grossly violated in action of dramatic role of the law enforcers i.e., the police. Furthermore, as a matter of great regret after reviewing certain case studies, it would not be irrelevant to state that investigations of certain sensational cases relating to the violations specially rape and murder have not been completed yet to submit the actual reports for ensuring justice. Therefore, it can be said that the status of women and children could get their rights and respects back when the government will take necessary steps for ensuring justice and accountability over the law enforcers' by the proper implementation and application of law in a country like Bangladesh, then it would not be difficult to ensure human rights in a democratic and developing country like Bangladesh.

\section{ACKNOWLEDGEMENT}

This study was supported with proper supervision and help of Professor Dr. M. Anisur Rahman, Department of Law, University of Rajshahi, Bangladesh.

\section{CONFLICTS OF INTEREST:}

The author declared no prospective conflicts of the interest with respect to the research work.

\section{REFERENCES:}

1. "968 children killed in 43 months." (August 8, 2015). The Daily Protho Alo. Accessed July 7, 2017.

http://en.prothomalo.com/bangladesh/news/7459 5/968-children-killed-in-41-months

2. "Five people including three children were allegedly tortured at Lalbagh Police Station custody in Dhaka," Odhikar, accessed March 30, 2018.

http://odhikar.org/five-people-including-threechildren-were-allegedly-tortured-at-lalbaghpolice-station-custody-in-dhaka/

3. "Khadija fighting for life." (October 5, 2016). The Daily Independent. Accessed July 10, 2017.

http://www.theindependentbd.com/post/62774

4. "More Bangladeshi girls harassed online than ever," DW, (April 19, 2017). Accessed January 2, 2018.

http://www.dw.com/en/more-Bangladeshi-girlsharassed-online-than-ever/a-38485906

5. "The Commercial Sexual Exploitation of Children in South Asia." ECPAT International, (2014). Quoted in Md. Moqsud Malek, Human Rights Bangladesh, 2016, (Dhaka: Ain o Salish Kendra (ASK), December 2017), 124.

http://www.ecpat.org/wpcontent/uploads/2016/0 4/Regional\%20CSEC\%20Overview_South\%20 Asia.pdf

6. "Willes Little Flower student Risha dies three days after knifed by miscreant." (August 28, 2016). The bdnews24.com accessed June 17, 2017.

https://bdnews24.com/bangladesh/2016/08/28/w illes-little-flower-student-risha-dies-three-daysafter-knifed-by-miscreant

7. Data collected from Ain o Sailsh Kendra (ASK) Data Conservation Unit's Statistics 2016 quoted in Suborna Dhor, Human Rights Bangladesh, 2016, (Dhaka: Ain o Salish Kendra (ASK), December 2017), 111-114. 
8. Data collected from Ain o Sailsh Kendra (ASK) Data Conservation Unit's Statistics 2016, quoted in Md. Moqsud Malek, Human Rights Bangladesh, 2016, (Dhaka: Ain o Salish Kendra (ASK), December 2017), 118.

9. Data collected from Ain o Sailsh Kendra (ASK) Data Conservation Unit's Statistics 2016, quoted in Nina Goswami, Human Rights Bangladesh, 2016, (Dhaka: Ain o Salish Kendra (ASK), December 2017), 140.

10. Data collected from Ain o Salish Kendra (ASK) Investigation Unit's reports-2016, quoted in Suborna Dhor, Human Rights Bangladesh, 2016, (Dhaka: Ain o Salish Kendra (ASK), December, 2017), 111. http://www.askbd.org/ask/

11. Data collected from the Prothom Alo, the Daily Sangbad, the Daily Ittefaq, the Daily Nayadiganta, the Daily Star, the Daily New Age, Dhaka Tribune and Ain o Salish Kendra (ASK), quoted in Md. Moqsud Malek, Human Rights Bangladesh, 2016, (Dhaka: Ain o Salish Kendra (ASK), December 2017), 118.

12. Dewan, Elira. (December 2017). Human Rights Bangladesh, 2016, [Dhaka: Ain o Salish Kendra (ASK)], 104.

13. Dhor, Suborna. (December 2017). Human Rights Bangladesh, 2016, [Dhaka: Ain o Salish Kendra (ASK)], 111-112. Accessed May 17, 2018.

http://www.askbd.org/web/wp-content/uploa ds/2012/08/HR_Situation_Bangladesh_2011.pdf
14. Islam, Md. Nahidul. "Human Rights Situation in Bangladesh: A Study with Special Reference to the Role of Police." PhD thesis. University of Rajshahi, 2018.

15. Islam MN. (2019). A Comparative Study Relating to Community Policing in the Context of Bangladesh, Br. J. Arts Humanit., 1(6), 56-72. https://doi.org/10.34104/bjah.019.56072

16. Malek, Md. Moqsud. (December 2017). Human Rights Bangladesh, 2016, [Dhaka: Ain o Salish Kendra (ASK)], 119.

17. Rahman, Masudur. (March 20, 2018). "Tonu murder: Killers still out of reach," the Daily Observer. Accessed May 16, 2018. https://observerbd.com/details.php?id=128364

18. The Daily Prothom Alo, (April 25, 2015). https://mail.google.com/mail/u/0/\#inbox/162b05 $\mathrm{d} 5 \mathrm{~b} 32 \mathrm{c} 96 \mathrm{~b} 8$

19. The Daily Sangbad, (October 31, 2016). Quoted in Suborna Dhor, Human Rights Bangladesh, 2016, (Dhaka: Ain o Salish Kendra (ASK), December 2017), 113.

20. The Daily Star, (April 27, 2017). Accessed April 20, 2108.

http://epaper.thedailystar.net/index.php?opt=vie w\&page $=6 \&$ date $=2017-04-27$

21. The Daily Star, (May 10, 2017). Accessed May 16, 2018.

http://epaper.thedailystar.net/index.php?opt=vie w\&page $=1 \&$ date $=2017-05-10$

Citation: Islam MN. (2020). The impact of human rights violation concerning the status of women and children in Bangladesh: a critical review, Br. J. Arts Humanit., 2(1), 1-13. https://doi.org/10.34104/bjah.02001013 (C) 